\title{
Jean-Pierre Dupouy, La figure de Peithô, déesse de la persuasion, dans la poésie de Ronsard
}

\section{Michele Mastroianni}

\section{(2) OpenEdition}

1 Journals

\section{Edizione digitale}

URL: http://journals.openedition.org/studifrancesi/403

DOI: $10.4000 /$ studifrancesi.403

ISSN: 2421-5856

\section{Editore}

Rosenberg \& Sellier

\section{Edizione cartacea}

Data di pubblicazione: 1 aprile 2015

Paginazione: 136

ISSN: 0039-2944

\section{Notizia bibliografica digitale}

Michele Mastroianni, « Jean-Pierre Dupouy, La figure de Peithô, déesse de la persuasion, dans la poésie de Ronsard », Studi Francesi [Online], 175 (LIX | I) | 2015, online dal 01 avril 2015, consultato il 18 septembre 2020. URL : http://journals.openedition.org/studifrancesi/403 ; DOI : https://doi.org/ 10.4000/studifrancesi.403

Questo documento è stato generato automaticamente il 18 settembre 2020.

\section{(c) 9 (i) $\Theta$}

Studi Francesi è distribuita con Licenza Creative Commons Attribuzione - Non commerciale - Non opere derivate 4.0 Internazionale. 


\title{
Jean-Pierre Dupouy, La figure de Peithô, déesse de la persuasion, dans la poésie de Ronsard
}

\author{
Michele Mastroianni
}

\section{NOTIZIA}

JEAN-PIERRE DUPOUY, La figure de Peithô, déesse de la persuasion, dans la poésie de Ronsard, «Revue des Amis de Ronsard», XXVII, 2014, pp. 43-65.

1 Partendo dall'analisi del sonetto XXXII delle Amours - un elenco della qualità di cui le divinità adornano la Cassandre amata dal poeta -, l'A. si sofferma sul significato che riveste il dono - la voix - fatto alla donna dalla dea Persuasione (Peithô). Nel sonetto infatti viene capovolta l'immagine esiodea di Zeus che invia agli uomini un regalo avvelenato: la donna, appunto, che con la voce (la parola) ingannerà i miseri mortali. Ronsard invece per celebrare la sua donna crea un'“altra" Pandora, che non "persuade" per ingannare, bensì per esercitare un fascino positivo. L'articolo passa in rassegna vari passi ronsardiani in cui la tematica della parola/persuasione compare e li mette in parallelo con la trattazione analoga del tema da parte di poeti contemporanei (Baïf, Pontus de Tyard, Belleau); così pure analizza i differenti significati che assume, in testi ronsardiani celebrativi, la stessa nozione di Peithô. 